\title{
The Principle of a Single Estate and Its Role in Delimiting the Applicable Laws
}

\begin{abstract}
This paper argues that the principle of unity of succession is one of the key concepts of the Succession Regulation. By operation of this principle on the jurisdictional level, the Regulation tends to favor a perspective of a single Member State when it comes to all issues related to succession. The principle of unity of succession does not of course eliminate the need to proceed to the characterization and to delimitate the scopes of conflict of laws rules at stake. However, this principle - aiming to promote a unitary vision of a single estate in all the Member States bound by the Regulation - sets a tone for some interpretative techniques that tend to favor succession-related characterization of the issues having some importance in the context of succession with cross-border implications. According to the Author, effet utile-driven characterization, on the one hand, and succession-friendly characterization of the issues falling within 'gray areas' created by the operation of Article 1(2) of the Succession Regulation, on the other hand, are among them.
\end{abstract}

Keywords: EU Succession Regulation - principle of unity of succession - characterisation (classification)

a) Dr, Legal clerk at the Court of Justice of the European Union. 


\section{Introduction}

The principle of a single estate, most commonly referred to as 'the principle of unity of succession' or 'the monist principle"1 and widely recognizable under its French denomination of "principe de l'unité de la succession', echoes a traditional debate relating to the international successions where it is opposed to 'the principle of scission' or 'the dualist principle'2.

In a general sense, the principle of unity of succession seeks to ascertain that a single law is applicable to all inheritance property in order to facilitate the settlement of international successions ${ }^{3}$. It can be argued, however, that it does so without taking into account the need to promote international consistency in addressing the matters of succession or at least that it disregards the differencing solutions.

In more detailed terms, on the one hand, the unity of succession aims to prevent a 'horizontal' ('territorial', 'spatial') division of the succession - that is to say, the inheritance in its entirety, movable and immovable assets included, should be governed by a single law. On the other hand, this principle aims to prevent division of the succession in 'vertical' ('temporal') sense. A single law should therefore apply in relation to

${ }^{1}$ See A. Davì, in: The EU Succession Regulation. A Commentary. Eds. A.-L. Calvo Caravaca, A. Davì, H.P. Mansel. Cambridge 2016, p. 3.

2 This debate has inspired a voluminous body of literature long prior to the enactment of EU private international law provisions on succession. See, among others, H. Li: Some recent developments in the conflict of laws of succession. "Recueil Des Cours de l'Académie de La Haye" 1990, vol. 224, p. 22 and seq.; E. Rabel: The Conflict of Laws: A Comparative Study. Volume Four Property: Bills and Notes: Inheritance: Trusts: Application of Foreign Law: lntertemporal Relations. Michigan 1958, p. 268 and seq.; A. Grahl-Madsen: Conflict between the Principle of Unitary Succession and the System of Scission. "International and Comparative Law Quarterly" 1979, vol. 28, no. 4, p. 598 and seq. For a brief overview of solutions existing in the Member States in this respect prior to the date of application of the Succession Regulation see M. Pazdan: Statut spadkowy w świetle rozporzadzenia spadkowego. In: Nowe europejskie prawo spadkowe. Eds. M. Pazdan, J. Górecki. Warszawa 2015, p. 95.

${ }^{3}$ See A. Wysocka-Bar: Jurysdykcja krajowa sqdów polskich a kolizyjna jednolitość spadku. "Problemy Współczesnego Prawa Międzynarodowego Europejskiego i Porównawczego" 2016, vol. XIV, p. 91. It is also argued that the unity of succession does not only address the particular needs of the conflict of laws but also reflects more faithfully the universal character of the succession recognised under some of the substantive laws. See D.A. Popescu: Guide on international private law in successions matters. Oneşti 2014 , p. 40 et seq. See also, for examples of legal systems in which the universal character of succession inspired the recognition of the principle of a single estate in the realm of private international law, A. Grahl-Madsen: Conflict..., p. 601. 
the whole succession process, from its opening to the final distribution of the assets ${ }^{4}$.

Against this background, the reference to the principle of unity of succession in the context of the delimitation between succession law and other applicable laws may be a priori surprising or even feel misguided. The principle of unity of succession is mainly oriented towards the internal unity of the law applicable to succession and not towards the external boundaries of this law or its interplay with other applicable laws. It may therefore be questioned whether this principle can play any significant role with regard to the delimitation of applicable laws. Yet, it seems that at least in the context of the Succession Regulation and its iteration of the principle of unity of succession, this question may surprisingly call for an affirmative answer.

\section{Principle of a single estate under the Succession Regulation}

It is the first paragraph of Article 21(1) of the Succession Regulation, headed 'General rule', that clarifies the choice made by the EU legislator in favor of the unitary approach to the international succession. It does so by indicating that 'the law of the State' designated as applicable under this provision by a connecting factor of 'habitual residence' is applicable to the 'succession as a whole'. That interpretation is borne out by Recital 37 of the Regulation which affirms that, for the sake of legal certainty and in order to avoid the fragmentation of the succession, a single law should govern 'all of the property forming part of the estate, irrespective of the nature of the assets and regardless of whether the assets are located'. This Recital is a nod to the 'horizontal' ('territorial', 'spatial') dimension of the principle of unity of succession. However, the listing of

${ }^{4}$ The distinction between 'horizontal' and 'vertical' unity is framed in these exact terms, inter alia, by A. Davì, in: The EU..., p. 37; P. Lagarde, in: EU Regulation on Succession and Wills. Commentary. Eds. U. Bergquist, D. Damasceli, R. Frimston, P. Lagarde, F. Odersky, B. Reinhartz. Koln 2015, p. 29. Some other authors distinguish the unity of the succession as to the assets and liabilities, on the one hand, and the unity of the succession as to the matters (issues) of succession, on the other hand. See A. Metallinos, in: EU Succession Regulation No 650/2012: A Commentary. Ed. H. Pamboukis. Oxford 2017, p. 241-243. Similarly, A. Bonomi, in: Le droit européen des succession, Commentaire du règlement (UE) $n^{\circ} 650 / 2012$, du 4 juillet 2012. Eds. A. Bonomi, P. Wautelet. Bruxelles 2016, p. 364 et seq., distinguishes between the unity in relation to the assets ('l'unité par rapport au biens successoraux') and the unity in relation to the issues governed ('l'unité par rapport aux questions régies'). 
issues falling with the scope of the law applicable under the conflict of laws rules of the Succession Regulation, provided by Article 23, makes it clear that, under this Regulation, the unitary approach extends also to the 'vertical' ('temporal') dimension of the unity ${ }^{5}$. A dépeçage resulting from the parallel application of multiple laws is a priori excluded. To that end, the connecting factor of 'habitual residence' must lead to the application of one legal system to the succession in its entirety ${ }^{6}$.

The emphasis on the unity of the succession should be followed, in my view, not only with regards to Article 21(1) of the Regulation that relies on the connecting factor of 'habitual residence' but also in respect to Articles 21(2) and 22 of the Regulation and their respective connecting factors of State manifestly more closely connected with the deceased and of nationality of the deceased. Firstly, the reasons justifying the avoidance of fragmentation of the succession under Article 21(1) of the Succession Regulation do not lose their relevance solely due to the fact that a different connecting factor is used. Secondly, the conflict of laws rules contained in Articles 21 and 22 refer to 'the law' of the State that meets the requirement set by the connecting factors and use, in general, the terminology implying that only a single law governs the succession. Thirdly, neither the affirmation provided by Recital 37, nor the listing provided by the Article 23 confine themselves solely to Article 21(1) of the Regulation. Fourthly, if the principle of unity of succession is intended to be one of the key principles of the Regulation, there should be some compelling reasons to deviate from this principle. Articles 21(2) and 22 do not seem to offer any ${ }^{7}$.

${ }^{5}$ According to Article 23(2) of the Succession Regulation the law determined pursuant to Articles 21 and 22 of the Regulation shall govern the succession as a whole: from the issues related to the opening of the succession, through the powers of the heirs and of the legatees, to the sharing-out of the estate.

${ }^{6}$ It is worth noticing that in order to achieve the coordination between ius and forum mentioned in Recital 27 of the Succession Regulation, the connecting factor of 'habitual residence' is used also in the rule on jurisdiction of Article 4 of the Regulation. It is true that the functions of conflict of laws rules and rules on jurisdiction largely differ. However, if the pursuit of coordination was driving the EU legislator's choice of the connecting factors, it can be argued that they should receive the same interpretation irrespectively of the context in which they are being used. If anything, on the interpretation of the connecting factor of 'habitual residence' under Article 4, see footnote 13.

${ }^{7}$ In particular, an individual possessing multiple nationalities should not be allowed to frustrate the unity of succession by exercising the autonomy he or she is granted under Article 22 of the Succession Regulation. Such choice of law seems to be excluded by second phrase of Article 22(1) of the Regulation. However, some authors consider that the issue in question is not expressly addressed by the Regulation. See A. Makowiec: W kierunku harmonizacji prawa spadkowego w Unii Europejskiej-rozporzadzenie (UE) nr 650/2012 z 4 lipca 2012 r. "Roczniki Administracji i Prawa" 2013, vol. 13, p. 447. Even 
Notwithstanding the foregoing, it is widely acknowledged that under the Succession Regulation the principle of unity of succession has many facets $^{8}$, most of which deviate from its traditional understanding. It is, for instance, argued that by means of this principle the legislator is not only aiming to achieve an internal unity of law applicable to the succession $^{9}$, but also striving to ensure that a succession will be submitted, in its entirety, to one and the same court ${ }^{10}$. In order to achieve that goal, at least two requirements have to be met. One the one hand, the extent of jurisdiction, understood as the aspects of succession in respect to which, territorial-wise, a court holds jurisdiction, should not be limited to a particular Member State ${ }^{11}$. On the other hand, the connecting factors used by the Regulation have to be constructed as to lead to the conferral of the jurisdiction to the courts of a single Member State ${ }^{12}$. Both these require-

if that is the case, the choice of law is inherently limited under the terms of Article 22 and it does not seem that the EU legislator was intending to sacrifice the unitary approach for the sake of autonomy to choose the applicable law.

${ }^{8}$ A. Bonomi, in: Le droit européen des succession... Eds. A. Bonomi, P. Wautelet, p. 364 .

${ }^{9}$ See P. Lagarde, in: EU Regulation..., p. 24, 29 who takes the view according to which the principle of unity of succession encompasses the unity of law applicable and the unity of jurisdiction. See also A. Wysocka-Bar: Jurysdykcja..., p. 103, who draws a distinction between 'the unity of ius' and 'the unity of forum'.

${ }^{10}$ This view seems to be shared by, inter alia, P. Lagarde who states 'the principle idea motivating the originators of the Regulation is that of unity: unity of succession, meaning that the inheritance in its entirety, both movable and immovable, will be governed by a single law and submitted to the same court, both at the level of judicial and of legislative competence'. See P. Lagarde, in: EU Regulation..., p. 24. Similar view is taken by A. Davì, in: The EU..., p. 37, who contends that 'the principle implies that one single judicial authority has jurisdiction on the succession and one law is applicable to it'. In this vein, P. Kindler: The General Rule: The 'Last Habitual Residence' of the Deceased and 'the Closer Connection' are objective connecting factor determining the law applicable to the succession. In: Towards the Entry into Force of the Succession Regulation:Building Future Uniformity upon Past Divergencies. Eds. S. Bariatti, I. Viarengo, F.C. Villata. JUST/2013/JCIV/AG/4666, argues that the principle of unity of succession is provided for in Article 21 of the Succession Regulation and confirmed by, inter alia, Article 4 of this Regulation.

${ }^{11}$ Indeed, Article 12(1) of the Succession Regulation seems to imply that, under the Regulation, the extent of general jurisdiction is not limited to a specific territory within the EU. It follows from this provision that a court of a Member State may decide not to pronounce itself on the assets located in a third State if that court anticipates refusal of recognition or enforcement of its future judgment. The limitation lies therefore within the practical effectiveness of a judgment due to the potential difficulties with its recognition and/or enforcement in a third State and not within a limitation of the extent of jurisdiction inherent to all of the rules on jurisdiction of the Regulation.

${ }^{12}$ Under Article 4 of the Succession Regulation, it is the place of the habitual residence of the deceased at the time of death that serves as the main connecting factor in 
ments are - with some deviations discussed below - met under the Succession Regulation.

\section{Deviations from the principle of a single estate}

The pursuit of unity under the Succession Regulation is not absolute $^{13}$. It is subject to some derogations provided for by the Regulation both in relation to the conflicts of laws and jurisdictional issues.

On the conflict of laws level, the deviations from the principle of unity of succession occur due to the operation of Articles 29 (special rules on the appointment and powers of an administrator), 30 (overriding mandatory rules), 31 (adaptation), 32 (commorients), 33 (estate without a claimant), 34 (renvoi) and 35 (public policy exception). Interestingly, at least some of them can be prevented by the coordination between ius and forum ${ }^{14}$. It is yet to be seen whether, in order not to circumvent the

matters of succession. In order to maintain the proper functioning of the principle of unity of succession, that connecting factor would need to be interpreted as requiring that each person has, at the time of death, only one place of the habitual residence. The question whether such an interpretation is correct has been already referred to the Court of Justice in the case E.E., C-80/19. While the Court has not yet delivered its judgment, in his Opinion presented in that case (ECLI:EU:C:2020:230, points 41 to 44), Advocate General Campos Sánchez-Bordona took the view that the practical effectiveness of the Regulation requires Article 4 to be interpreted as implying that a deceased can have only single place of habitual residence within the meaning of this provision. At point 42 of the Opinion, Advocate General backs his interpretation with an argument drawn from the avoidance of the fragmentation of succession. Following this line of reasoning, also the connecting factors used in Article 5, 7, 9, 10(1) and 11 of the Regulation would also have to be interpreted as leading to the jurisdiction of the courts of a single Member State.

${ }^{13}$ In fact, R. Frimston argues that Article 21(1) of the Succession Regulation may be interpreted as a provision already flagging that the principle of unity of succession can be and indeed is deviated from under this Regulation. According to this provision, "unless otherwise provided for in this Regulation, the law applicable to the succession as a whole shall be the law of the State in which the deceased had his habitual residence at the time of death'. For this Author, Article 21(1) of the Regulation provides for a non-absolute character of the principle at least in relation to the law applicable to succession-related issues. See R. Frimston: The European Union Succession Regulation no. 650/2012. "Estates, Trusts \& Pensions Journal” 2013, vol. 33, p. 109.

${ }^{14}$ Against this background, D.A. Popescu: Guide..., p. 39, contends that 'the principle of inheritance unity' has two aspects: on the one hand, the application of a single law to the succession and, on the other hand, the identity between the applicable law and the competent authority. While it is doubtful whether the coordination between ius and 
principle of unity of succession underlying the Regulation, these Articles will receive a strict interpretation ${ }^{15}$. Surprisingly, the opposite might be inferred from a reading of Article 34. In fact, the unity of succession operating on conflict of laws level is sacrificed for the sake of 'international consistency' underlying this provision ${ }^{16}$ : while at least to a certain extent a renvoi promotes the solutions of third States [and protects the application of the law of a Member State under Article 34(1)(b)], it does so without requiring a unitary end result of its operation ${ }^{17}$. In this respect, it may be argued that all the derogations from the principle of a single estate in its conflict of laws incarnation were put in place in order to ensure such 'international consistency'.

On the jurisdictional level, the derogations from the principle of unity of succession may occur in instances to which references are made in Articles 10(2) and 12 of the Succession Regulation ${ }^{18}$. They may also occur in the instances referred to in Article 11 of the Regulation, if it is accepted that the extent of jurisdiction of the forum of necessity is limited to the assets located in the Member State of this forum and, potentially, also to the assets located in a third State with which the case is closely connected and where the proceedings cannot reasonably be brought or conducted or would be impossible to conduct. Besides, in a certain parallel to the operation of renvoi under Article 34 which protects the application of the law of a Member State, the Regulation does not favor the unity of succes-

forum - understood as a situation where a competent court applies its own law - has to be necessarily perceived as an element of the principle of a single estate, such coordination definitely operates in favor of the unity of succession. It may prevent the application of multiple legal orders to a single succession as a result of the operation of Articles 29(1) (special rules of the forum on the administrator of the estate) and 35 (public policy of the forum). Similarly, Article 31 of the Succession Regulation allows for adaptation where there is a divergence between the jurisdiction and applicable law and these two legal systems differ on the recognition of a certain type of right in rem. The lack of such divergence would eliminate the very reason for the recourse to adaption. See, a contrario, A. Lehavi: Globalizing Property Law: An Institutional Analysis. "Vanderbilt Journal of Transnational Law" 2017, vol. 50, no. 5, p. 1201.

15 See, in relation to Article 30 of the Succession Regulation, E. Lein: A Further Step Towards a European Code of Private International Law - The Commission Proposal for a Regulation on Succession. "Yearbook of Private International Law" 2009, vol. XI, p. 125.

${ }^{16}$ See Recital 57 of the Succession Regulation.

17 See W. Popiołek, in: Prawo prywatne międzynarodowe. Komentarz. Red. M. Pazdan. Warszawa 2018, komentarz do art. 34 rozporządzenia nr 650/2012, pkt 6. See also A. Devaux: The European Regulations on Succession of July 2012: A Path Towards the End of the Succession Conflicts of Law in Europe, or Not? "The International Lawyer" 2013, vol. 47, no. 2, p. 237.

${ }^{18}$ See F. Marongiu Buonaiuti: The EU Succession Regulation and third country courts. "Journal of Private International Law" 2016, vol. 12, no. 3, p. 562-563. 
sion to the extent that would require a court of a Member State to decline its jurisdiction in favor of a court of a third State being in the position to ensure the complete application of the principle of a single estate ${ }^{19}$.

\section{Delimitation of applicable laws in the light of the principle of a single estate}

The admission of all the aforementioned derogations from the principle of a single estate does not imply that the EU legislator forsakes the pursuit of unity. They only partially affect this principle and are generally specific circumstances related ${ }^{20}$. As such, they do not change the logics of the Regulation: it still favors an inward trend towards a perspective of a single Member State when it comes to all issues related to succession. It remains true even if it happens to be only a facade of unity created by the operation of the rules on jurisdiction and not by application of uniform rules on conflict of laws.

In fact, the conferral of jurisdiction to the courts of a single Member State leads to a situation where - within the whole territory of the Union and even beyond, provided that a decision rendered under the Succession Regulation will be enforced or recognized in a non-Member State both the incidental questions and the issues falling outside the scope of uniform conflict of laws rules of that Regulation can be addressed from the perspective of a single set of private international law rules applied by the competent court. The delimitation of the laws governing the issues excluded from the scope of the Regulation is exercised by a single Member State and then extrapolated to the States where the decisions

${ }_{19}$ Articles 6, 8 and 9(2) of the Succession Regulation concern the situation where the jurisdiction is declined in favor of a court of a different Member State and under Article 12 of this Regulation the discretion of a court does not go so far as to allow it to decline completely its jurisdiction. See also K. Knol Radoja: Deviations from the Principle of the Unity of Succession in the EU Regulation on Succession. "Pravni Vjesnik" 2019, vol. 35 , no. 2 , p. $55-56$.

20 This is in particular the case of the derogations operating on the jurisdictional level. See also M. Lew andowska-Mroczkowska: Jurisdiction in the Succession Matters under the Regulation (EU) no 650/2012 of the European Parliament and the Council of 4 July 2012 in the Face of Polish International Civil Procedure. "Social Transformations in Contemporary Society" 2019, vol. 7, p. 154, who identifies "the principle of unity of forum' as a general rule of the Regulation and argues that it is derogated in a very limited number of cases. 
rendered under this Regulation are enforced or recognized. However, the principle of unity of succession operating on jurisdictional level cannot, by itself, guarantee that the objectives of the Regulation will be effectively met.

\section{Characterization and the effectiveness of the Regulation}

The delimitation of applicable laws ultimately boils down to the issue of characterization ${ }^{21}$ and the conflict of laws strategy that the Regulation adopts makes the courts of a single Member State primarily responsible for dealing with that issue.

Against this background, the terms which the Succession Regulation uses to define its scope and the scope of the law applicable to the succession under Article 21(1) are subject to autonomous interpretation. The interpretation of those terms must therefore take account of the objectives of the Regulation, which - in line with the clarifications provided by the Recitals - are to eliminate obstacles to the free movement of persons within the internal market and ensure that the rights of the heirs are effectively guaranteed in the Member State ${ }^{22}$. To this end, the Succession Regulation introduces the European Certificate of Succession (ECS), intended to enable succession with cross-border implications within the European Union to be settled speedily, smoothly and efficiently ${ }^{23}$.

Indeed, the ECS is an instrument that allows for an effective enforcement of a conflict of laws strategy that the Succession Regulation establishes: a succession with cross-border is to be dealt coherently by a single court applying one single law ${ }^{24}$.

In this context, the person mentioned in an ECS as a heir or a legatee is to be presumed to have the status and the rights stated in the certificate with no conditions or restrictions other than those provided for in the certificate ${ }^{25}$. The ECS produces its effects in all Member States and is not subject to the public policy exception ${ }^{26}$. However, it can be inferred from Article 69(2) of the Succession Regulation read in the light of the

${ }^{21}$ See D. Salomon: The Boundaries of the Law Applicable to Succession. "Anali Pravnog Fakulteta Univerziteta u Zenici” 2016, Issue 18, p. 193.

${ }^{22}$ See Recital 7 of the Sucession Regulation.

${ }^{23}$ See Recital 8 of the Sucession Regulation.

${ }^{24}$ A. Lehavi: Globalizing Property Law..., p. 1202.

${ }_{25}$ See Article 69(2) of the Succession Regulation.

${ }^{26}$ See Article 69(1) of the Succession Regulation. 
third sentence of recital 71 of this Regulation that the evidentiary effect of an ECS does not extend to issues which do not fall within the scope of this Regulation. As a result, an element relating to a matter excluded from the scope of lex successionis ${ }^{27}$ — or any other law determined as applicable under the Succession Regulation ${ }^{28}$ — , revealed in the ECS among its other elements, is not covered by the evidentiary effects provided for in Article 69.

This is, in a nutshell, one of the arguments that guided the Court of Justice in its judgment in Mahnkopf ${ }^{29}$. In essence, in this case the Court was asked to rule whether a quarter of the estate attributable under Paragraph 1371(1) of the German Civil Code (BGB) to a surviving spouse should receive a succession-related characterization and therefore fall within the scope of the lex successionis. This question was answered in affirmative. Alongside two other main arguments, the Court found, in line with Advocate General Szpunar ${ }^{30}$, that in order for the provisions of the Succession Regulation providing for a regime of the ECS to maintain their effectiveness, a national provision such as Paragraph 1371(1) of the BGB should fall within the scope of the Regulation. As a matter of consequence, the scope of lex successionis has to be interpreted as to include the surviving spouse's share in the estate attributable to that spouse under a national provision such as Paragraph 1371(1) of the BGB ${ }^{31}$. Thus, it can be argued that the succession-related characterization of certain issues may be driven by the concern to preserve effet utile of the Succession Regulation.

The Mahnkopf case illustrates that the unity of succession operating on jurisdictional level is not able to guarantee the full effectiveness of the Succession Regulation. The fact that an ECS is delivered by the courts of a single Member State is not sufficient for this certificate to produce its evidentiary effects in respect to the issues that do not receive a succession-related characterization. This is of course a consequence of

${ }^{27}$ Article 21 of the Succession Regulation.

28 Article 24-28 of the Succession Regulation.

29 Judgment of 1 March 2018, Mahnkopf, C-558/16, EU:C:2018:138.

${ }^{30}$ See Opinion of Advocate General Szpunar in Mahnkopf, C-558/16, EU:C:2017:965, point 114 .

${ }^{31}$ The same logic should apply in relation to other provisions that share the characteristics of Paragraph 1371(1) of the BGB. Furthermore, for an illustration of provisions of different nature that may cause difficulties in relation to their characterization see A. Bonomi: The Interaction among the Future EU Instruments on Matrimonial Property, Registered Partnerships and Successions. "Yearbook of Private International Law" 2011, vol. 13, p. 219-220; P. Wautelet, J. Mary: Le règlement 650/2012 relatif aux succession internationales. Aperçu et principes généraux. "Journal des tribunaux" 2016, n 23, p. 379. 
the interpretation of Article 69(2) of the Succession Regulation according to which the evidentiary effect of an ECS does not extend to elements established under the conflict of laws rules other than those contained in the Regulation ${ }^{32}$.

Moreover, the Mahnkopf case did not give rise to an issue that could have arguably even strengthened the need to resort to the characterization of Paragraph 1371(1) of the BGB as a succession-related matter. In this case, the German law governed both the succession and the matrimonial property regime. However, a case may have to be decided in accordance to several legal systems governing different issues having particular importance for the international succession. These systems may not be synchronized with each other. That would be a case where both the inheritance and matrimonial property regimes would grant a considerable share in the estate to the surviving spouse. It could lead to a distribution of assets excessively favoring this spouse to the detriment of other heirs. In order to remedy such shortcomings, it may be necessary to have recourse to the adaptation (adjustment) of the applicable laws in question ${ }^{33}$. Adjustment may result in a synthesis of these laws ${ }^{34}$. The inconsistencies would be addresses on the substantial level, without affecting the conflict of laws rules. Thus, on the substantial level, a balanced solution could be achieved.

However, in most instances the recourse to the adjustment would result in a synthesis of two (or more) applicable laws, at least one of them not being designed as applicable by the conflict of laws rules established

${ }^{32}$ It is true that the wording of Article 69(2) of the Succession Regulation could be also subject to a different interpretation. According to this provision ' $[\mathrm{t}]$ he [ECS] shall be presumed to accurately demonstrate elements which have been established under the law applicable to the succession or under any other law applicable to specific elements'. No reference to the conflict of laws rules of the Succession Regulation is made in this provision. However, a purely textual interpretation of Article 69(2) of the Regulation would lead to a situation where the evidentiary effects are extended to the content of law designated as applicable under national conflict of laws rules that do deeply vary among the Member States. Recital 71 of the Regulation clarifies that this was not the solution that the EU legislator was trying to adopt in the Regulation. The interpretation limiting the evidentiary effects of an ECS to the elements established under the conflict of laws rules of the Succession Regulation was ultimately confirmed by the Court in its judgment of 1 March 2018, Mahnkopf, C-558/16, EU:C:2018:138.

${ }^{33}$ See Opinion of Advocate General Szpunar in Mahnkopf, C-558/16, EU:C:2017:965, point 62. For a general overview of the adjustment in private international law see G. Dannemann: Adjustment/Adaptation (Anpassung). In: Encyclopedia of private international law. Eds. J. Basedow, G. Ruhl, F. Schiller, F. Ferrari, P. de Miguel Asensio. Cheltenham 2017, p. 8 et seq.

${ }^{34}$ G.A.L. Droz: Les régimes matrimoniaux en droit international privé comparé. „Recueil des cours de l'Académie de la Haye” 1974, vol. 143, p. 98. 
by the Succession Regulation. Would the outcome of the adjustment, reproduced in the ECS, benefit, at least partially, from the evidentiary effects provided for in Article 69(1) of the Regulation? Due to the interpretation of Article 69(2) that was ultimately adopted in the Mahnkopf case, that question would most probably have to be answered in the negative. The fused result of the adjustment does not correspond to the content of the law that is designated as applicable law under the Regulation. That would imply that the adjustment operating on the substantial level leads to a highly unsatisfying result at least from the perspective of the succession with cross-border implications settled with recourse to an ECS.

A different form of adjustment would be therefore preferred under the Succession Regulation, namely the one that operates on the conflict of laws level and relies on the revision of the scope of the concerned rules of private international law.

It is true that the adjustment operating on the conflict of laws level can lead to a creation of a new (conflict of laws) rule that designates the law governing the issues that provoked the very need to resort to the adjustment ${ }^{35}$. In relation to the ECS, this form of adjustment would, however, be burdened by the shortcomings that manifest when a synthesis of applicable laws is being created on the substantial level. Such a newly created 'hybrid' conflict of laws rule could be hardly considered as a rule established by the Succession Regulation. As a consequence, the content of law designated as applicable by this rule would not benefit from the evidentiary effect provided for in Article 69(1) of the Succession Regulation. Therefore, even where the adjustment is operating on the conflict of laws level, in order to preserve the effectiveness of the provisions of the Regulation that introduce the ECS, a succession-related characterization of all the concerned issues may be preferred from the viewpoint of this Regulation.

For the sake of completeness, the trend towards succession-related characterization aiming to achieve a unity of succession should not be limited to the instances where the succession is settled by means of an ECS. In fact, an individual can always have recourse to an ECS and the way the delimitation of applicable laws is approached cannot be altered by his choice to do so. Moreover, that trend may be also inspired by other considerations having universal relevance.

35 See A. Köhler: General Private International Law Institutes in the EU Succession Regulation - Some Remarks. "Anali Pravnog Fakulteta Univerziteta u Zenici" 2016, Issue 18, p. 180. 


\section{Boundaries of the consensus}

A number of issues a priori excluded from the scope of application of the Succession Regulation and, as a consequence, from the scope of lex successionis, may be of particular importance in the context of succession with cross-border implications. According to the listing contained in Article 1(2) of this Regulation not only the questions relating to matrimonial property regimes and property regimes of relationships having effects comparable to marriage do not fall within the scope of the Regulation, but also, inter alia, the questions relating to the property rights, interests and assets created or transferred otherwise than by succession as well as the questions governed by the law of companies and other bodies.

It can be inferred from the architecture of the Regulation that the EU legislator did hope for a future unification of conflicts of laws rules in respect to other areas that may enter into interactions with the succession law. At least some of the exclusions listed in Article 1(2) are reminiscent of EU private international law instruments on which work has already been completed or is in progress. Unsurprisingly, the scopes of the Succession Regulation and such other instruments are meant not to overlap $^{36}$. Moreover, if uniform conflict of law rules on the matrimonial property regimes existed in all of the Member States, the issue related to the evidentiary effects of an ECS which surfaced in the Mahnkopf case [due to the interpretation of Article 69(2) of the Succession Regulation limiting the evidentiary effects of the Certificate to the elements established under conflict of laws rules of the Regulation] could have been most probably solved without the necessity to resort to succession-related characterization of Paragraph 1371(1) of the BGB. Of course, taking into account the wording of Article 69(2) of the Succession Regulation according to which the evidentiary effects extends to the 'elements which have been established under the law applicable to the succession or under any other law applicable to specific elements', as interpreted in the Mahnkopf case by the Court of Justice, it would not have been possible to achieve that result by relying on a simple textual interpretation of this provision. However, on the one hand, it cannot be ruled out that a similar result could have been achieved with recourse to the teleological interpretation of Article 69(2) of the Succession Regulation. On the other hand, the Regulation could have been amended to that effect.

${ }^{36}$ See judgments: of 6 October 2015, Matoušková, C-404/14, EU:C:2015:653, point 34; of 1 March 2018, Mahnkopf, C-558/16, EU:C:2018:138, point 41. 
Yet, the Succession Regulation was negotiated and adopted in a specific timeframe in the European Union history, in the very advent of EU private international law development, a few years after the initial date of application of the Rome and Maintenance Regulations. Conversely, despite the efforts made in this regard, no uniform conflict of laws rules have yet been elaborated in the areas of the EU law that are excluded from the scope of the Succession Regulation. Suffice it to mention that the efforts in relation to matrimonial property regimes and registered partnerships only yielded moderate success with the regulations adopted within the framework of enhanced cooperation. It does not seem that any major developments as to the questions of property rights or company law are to be expected in the nearest future. One could even argue that, at least in relation to some of these areas, the Succession Regulation already holds the ground at the boundaries of Member States' consensus.

However, the boundaries at which the Succession Regulation allegedly holds ground are not clearly defined. In fact, the interpretation of the exclusions provided for in Article 1(2) of the Succession Regulation can turn out to be a tedious task. So can be the delimitation of the law applicable to succession and other applicable laws. Some gray areas do still exist.

It would not be so surprising to see the scope of the lex successionis interpreted in a manner allowing to adopt a succession-related characterization of the issues falling within these gray areas. Desirable or not, it can be argued that such characterization allows to achieve what the EU legislator was not able to accomplish in relation to the development of uniform conflict of laws rules.

\section{Conclusion}

The principle of unity of succession is one of the key concepts of the Succession Regulation. By operation of this principle on the jurisdictional level, the Regulation tends to favor a perspective of a single Member State when it comes to all issues related to succession. These issues may be addressed by the laws designed as applicable by a single set of conflict of laws rules. To a certain extent, it allows to minimalize the shortcomings resulting from the lack of uniform conflict of law rules relating to the issues excluded from the scope of application of the Succession Regulation. Furthermore, the characterization of the issues that do not fall within the scope of the Regulation adopted in that single Member State is extrapo- 
lated to the other Member States due to the mechanisms of recognition and enforcement of the decisions rendered under the Regulation.

The principle of unity of succession does not, therefore, eliminate the need to proceed to the characterization and to delimitate the scopes of conflict of laws rules at stake. However, this principle - aiming to promote a unitary vision of a single estate in all the Member States bound by the Regulation — sets a tone for some interpretative techniques that tend to favor succession-related characterization of the issues having some importance in the context of succession with cross-border implications.

Firstly, the principle of unity of succession operating solely on the jurisdictional level fails to preserve the effectiveness (effet utile) of the Succession Regulation. A proper characterization of concerned issues may be far more promising in that respect. It can be driven by the concern to preserve the effectiveness of EU law and, more specifically, of provisions of the Succession Regulation. Besides, the concern to preserve the effectiveness of the Regulation affects also the way the adjustment should be approached in relation to the succession with cross-border implications. The adjustment operating on the substantial level may not be sufficient to preserve the effectiveness of the provisions of the Regulation that introduce the ECS. Therefore, it seems that the adjustment operating on the conflict of laws level may, at least in some instances, be preferred over the adjustment operating on the substantial level.

Secondly, at least in relation to some of the areas excluded from the scope of the Succession Regulation and not covered by other instruments of EU private international law, this Regulation already holds the ground at the boundaries of Member States' consensus. The characterization aiming to promote a unitary vision of a single estate allows to achieve what the EU legislator was not yet able to accomplish in relation to the development of uniform conflict of laws rules.

\section{References}

Bonomi A.: The Interaction among the Future EU Instruments on Matrimonial Property, Registered Partnerships and Successions. "Yearbook of Private International Law” 2011, vol. 13.

Bonomi A., in: Le droit européen des succession, Commentaire du règlement (UE) $n^{\circ}$ 650/2012, du 4 juillet 2012. Eds. A. Bonomi, P. Wautelet. Bruxelles 2016 . 
Dannemann G.: Adjustment/Adaptation (Anpassung). In: Encyclopedia of private international law. Ed. J. Basedow, G. Ruhl, F. Schiller, F. Ferrari, P. de Miguel Asensio. Cheltenham 2017.

Davì A., in: The EU Succession Regulation. A Commentary. Eds. A.-L. Calvo Caravaca, A. Davì, H.P. Mansel. Cambridge 2016.

Devaux A.: The European Regulations on Succession of July 2012: A Path Towards the End of the Succession Conflicts of Law in Europe, or Not? "The International Lawyer" 2013, vol. 47, no. 2.

Droz G.A.L.: Les régimes matrimoniaux en droit international privé comparé. "Recueil des cours de l'Académie de la Haye" 1974, vol. 143.

Frimston R.: The European Union Succession Regulation no. 650/2012. "Estates, Trusts \& Pensions Journal" 2013, vol. 33.

Grahl-Madsen A.: Conflict between the Principle of Unitary Succession and the System of Scission. "International and Comparative Law Quarterly" 1979, vol. 28 , no. 4.

Kindler P.: The General Rule: The 'Last Habitual Residence' of the Deceased and 'the Closer Connection' are objective connecting factor determining the law applicable to the succession. In: Towards the Entry into Force of the Succession Regulation:Building Future Uniformity upon Past Divergencies. Eds. S. Bariatti, I. Viarengo, F.C. Villata. JUST/2013/JCIV/AG/4666.

Knol Radoja K.: Deviations from the Principle of the Unity of Succession in the EU Regulation on Succession. "Pravni Vjesnik" 2019, vol. 35, no. 2.

Köhler A.: General Private International Law Institutes in the EU Succession Regulation - Some Remarks. "Anali Pravnog Fakulteta Univerziteta u Zenici" 2016, Issue 18.

Lagarde P., in: EU Regulation on Succession and Wills. Commentary. Eds. U. Bergquist, D. Damasceli, R. Frimston, P. Lagarde, F. Odersky, B. Reinhartz. Koln 2015.

Lehavi A.: Globalizing Property Law: An Institutional Analysis. "Vanderbilt Journal of Transnational Law" 2017, vol. 50, no. 5.

Lein E.: A Further Step Towards a European Code of Private International Law - The Commission Proposal for a Regulation on Succession. "Yearbook of Private International Law" 2009, vol. XI.

Lewandowska-Mroczkowska M.: Jurisdiction in the Succession Matters under the Regulation (EU) no 650/2012 of the European Parliament and the Council of 4 July 2012 in the Face of Polish International Civil Procedure. "Social Transformations in Contemporary Society" 2019, vol. 7.

Li H.: Some recent developments in the conflict of laws of succession. "Recueil Des Cours de l'Académie de La Haye" 1990, vol. 224.

Makowiec A.: W kierunku harmonizacji prawa spadkowego w Unii Europejskiej — rozporzqdzenie (UE) nr 650/2012 z 4 lipca 2012 r. "Roczniki Administracji i Prawa" 2013, vol. 13.

Marongiu Buonaiuti F.: The EU Succession Regulation and third country courts. "Journal of Private International Law" 2016, vol. 12, no. 3.

Metallinos A., in: EU Succession Regulation No 650/2012: A Commentary. Ed. H. Pamboukis. Oxford 2017. 
Pazdan M.: Statut spadkowy w świetle rozporzadzenia spadkowego. In: Nowe europejskie prawo spadkowe. Eds. M. Pazdan, J. Górecki. Warszawa 2015.

Popescu D.A.: Guide on international private law in successions matters. Oneşti 2014.

Popiołek W., in: Prawo prywatne międzynarodowe. Komentarz. Red. M. Pazdan. Warszawa 2018, komentarz do art. 34 rozporządzenia nr 650/2012, pkt 6.

Rabel E.: The Conflict of Laws: A Comparative Study. Volume Four Property: Bills and Notes: Inheritance: Trusts: Application of Foreign Law: Intertemporal Relations. Michigan 1958.

Salomon D.: The Boundaries of the Law Applicable to Succession. "Anali Pravnog Fakulteta Univerziteta u Zenici" 2016, Issue 18.

Wautelet P., Mary J.: Le règlement 650/2012 relatif aux succession internationales. Aperçu et principes généraux. "Journal des tribunaux" 2016, nº 23.

Wysocka-Bar A.: Jurysdykcja krajowa sadów polskich a kolizyjna jednolitość spadku. "Problemy Współczesnego Prawa Międzynarodowego Europejskiego i Porównawczego" 2016, vol. XIV. 